\title{
Pola Pendidikan Keluarga dalam Membendung Gaya Hidup Hedonis di Lingkungan Perindustrian
}

\author{
(Studi di desa Mentoso kec.Jenu kab.Tuban Jawa Timur)
}

Isnawati Nur Afifah Latif dan Nurlaili Dina Hafni

\begin{abstract}
Abstrak
Kecamatan Jenu merupakan salah satu kawasan industri yang terdapat di Kabupaten Tuban. Di daerah ini terdapat tiga industri besar, yaitu PT TPPI di desa Tasik Harjo, PT PJB PLTU di tanjung Awar-awar dan kilang minyak pertamina di desa Mentoso. Dengan adanya ketiga industri ini pada area yang berdekatan menyebabkan perekonomian ketiga desa tersebut juga meningkat. Seiring dengan meningkatnya perekonomian tersebut, maka mereka juga terpengaruh dengan gaya hidup hedonis yang banyak diikuti oleh masyarakat. Hal ini dibuktikan dengan pembelian barang mewah yang meliputi kendaraan bermotor, fashion dan makanan. Di desa Mentoso gaya hidup hedonis tidak terlalu terlihat dibandingkan di desadesa sekitarnya seperti Tasik Harjo, Tanjung Awar-awar dan Remen yang sangat terpengaruh oleh gaya hidup hedonis. Hal ini dapat dilihat dari pendidikan remaja di desa Mentoso, yakni para remaja mulai umur 12-18 yang lebih memilih belajar di pesantren. Berbeda dengan remaja di desa lainnya yang lebih bangga untuk bersekolah di kota. Dengan banyaknya remaja yang bersekolah di pesantren juga mempengaruhi gaya hidup dan fashion mereka. Mereka tidak terlalu mengunggulkan penampilannya. Pengetahuan dan pemahaman yang telah ditempuh di lembaga formal maupun informal mengakibatkan karakter baik, sopan, peduli dengan lingkungan, religius, dan sederhana. Tidak hanya akibat dari pendidikan, pola asuh yang dilakukan, orang tua juga berperan dalam hal ini. Para orang tua di Desa Mentoso menerapkan aturan yang jelas dengan mengharap sikap yang dewasa dari anak. Hal ini terlihat pada pemahaman akan konsekuensi dari perbuatan yang telah dilakukan. Para orang tua memberikan pemahaman dari contoh yang terjadi pada kesehariannya. Ketika mereka bekerja dengan tekun, maka hasil yang didapat juga akan berlimpah. Begitupun sebalikya. Ketika mereka dekat dengan Tuhan, melaksanakan apa yang diharuskan dalam agama dan menghindari apa yang dilarang dalam aturan agama, maka ketenangan yang didapat adalah ketenangan dan kenyamanan. Begitupun sebaliknya.
\end{abstract}

Kata Kunci : Pola pendidikan keluarga, Gaya hidup, Hedonis 


\section{A. PENDAHULUAN}

Tuban merupakan kabupaten yang memiliki lokasi strategis. Dilihat dari posisi, Kabupaten Tuban berada di jalan arteri primer yang menghubungkan ibukota propinsi Jawa Timur dengan ibukota propinsi Jawa Tengah. Sebagaimana yang dituliskan dinas pekerjaan Umum pada laman profil Kabupaten Tuban, Kabupaten Tuban dapat berperan sebagai "kota antara" sehingga dapat menjamin perkembangan ekonomi daerah lebih cepat. Kabupaten Tuban kaya akan sumberdaya, dari kekayaan laut, minyak bumi, bahan tambang dan sebagainya. Sumberdaya tersebut menyebabkan para investor tertarik untuk menanamkan modalnya di Tuban. Tuban dalam waktu yang akan datang diprediksi semakin berkembang. Hal ini dikarenakan akan didirikan pabrik besar seperti contoh Petrokimia dan juga pembuatan saluran gas dan minyak dari Cepu ke Tuban oleh Pertamina.

Perkembangan industri memang membawa dampak baik dan buruk sekaligus. Hal ini harus disikapi secara bijak bagi masyarakat dan investor. Investor harus bisa menjaga lingkungan masyarakat di sekitarnya dan masyarakat harus bisa menunjukan potensi daerahnya tanpa perlu terkena imbas perindustrian. Dengan berkembangnya kegiatan industri, selain menaikkan nilai ekonomi suatu komoditi, juga dapat membuka kesempatan ekonomi bagi masyarakat, yaitu memberikan alternatif lapangan kerja baru.

Sebuah lingkungan permukiman yang sehat, aman, harmonis dan berkelanjutan merupakan idaman setiap orang untuk mencapai kesejahteraan hidup dan menjamin kesehatan keluarga. Faktor penentu dari lingkungan pemukiman tersebut meliputi kondisi fisik rumah tinggal beserta lingkungan di sekitarnya, pola hidup individu dan komunitas, kondisi sosial, ekonomi-budaya, dan dukungan dari pemerintah melalui penyediaan prasarana dan sarana pelayanan (Margareth, 2011: 4).

Hedonisme terjadi karena adanya perubahan perilaku pada masyarakat yang hanya menghendaki kesenangan. Perilaku tersebut lama kelamaan mengakar dalam kehidupan masyarakat termasuk para remaja yang pada akhirnya menjadi seperti sebuah budaya bagi mereka tingkat pengetahuan dan pendidikan juga sangat berpengaruh pada pembentukan sikap mental para remaja. Banyak diantara para remaja yang melarikan diri dari masalah dengan berhura-hura. Kebiasaan seperti inilah yang kemudian menjadi kebudayaan di kalangan remaja. Berangkat dari masalah ini, penulis ingin memaparkan pengaruh budaya hedonisme terhadap remaja. 
Seperti yang diungkapkan oleh Kotler dan Amstrong (2002) faktor yang mempengaruhi gaya hidup hedonisme adalah faktor eksternal yaitu salah satunya keluarga. Faktor keluarga inipun salah satu faktor yang mempengaruhinya adalah pola pendidikan yang dilakukan oleh orang tua kepada anak-anaknya. Pola pendidikan yang diterapkan oleh orang tua akan berpengaruh terhadap pembentukan karakter anak. Keluarga adalah lingkungan yang pertama kali menerima kehadiran anak. Orang tua memiliki berbagai fungsi yang salah satu diantaranya adalah mengasuh anak-anaknya. Sikap tersebut akan tercermin dalam pola pengasuhan dan pola pendidikan yang diterapkan orang tua kepada anak-anaknya. Pola tersebut antara orang tua satu dengan lainnya. Disinilah peran pola asuh dan pola pendidikan anak akan mempengaruhi gaya hidup anak.

Kecamatan Jenu merupakan salah satu kawasan industri yang terdapat di Kabupaten Tuban. Di daerah ini terdapat tiga industri besar, yaitu PT TPPI di desa Tasik Harjo, PT PJB PLTU di tanjung Awar-awar dan kilang minyak pertamina di desa Mentoso. Dengan adanya ketiga industri ini pada area yang berdekatan menyebabkan perekonomian ketiga desa tersebut juga meningkat. Seiring dengan meningkatnya perekonomian tersebut, maka mereka juga terpengaruh dengan gaya hidup hedonis yang banyak diikuti oleh masyarakat. Hal ini dibuktikan dengan pembelian barang mewah yang meliputi kendaraan bermotor, fashion dan makanan. Selain itu untuk mencari hiburan mereka tidak ingin mencari biasa-biasa seperti ke pantai yang notabene kabupaten Tuban memiliki wisata pantai yang banyak. Mereka lebih memilih pergi ke Surabaya yang memiliki jarak kurang lebih $120 \mathrm{~km}$. Tanda lain yang dapat dilihat adalah semakin banyaknya tempat karaoke di kawasan kecamatan Jenu, yang mana tempat karaoke ini merupakan tempat prostitusi terselubung.

Desa Mentoso merupakan salah satu kawasan industri di kecamatan Jenu yang di dalamnya terdapat PT Tuban Petrochemical Industries (TPPI) yang didirikan pada tahun 1995. Desa Mentoso diapit oleh desa Tasik Harjo di sebelah barat dimana di desa tersebut terdapat PT TPPI dan PT Pertamina Persero serta PT PJB PLTU di sebelah timur desa Mentoso tepatnya di desa Tanjung Awar-awar.

Di desa Mentoso gaya hidup hedonis tidak terlalu terlihat dibandingkan di desadesa sekitarnya seperti Tasik Harjo, Tanjung Awar-awar dan Remen yang sangat terpengaruh oleh gaya hidup hedonis. Hal ini dapat dilihat dari pendidikan remaja di desa Mentoso, yakni para remaja mulai umur 12-18 yang lebih memilih belajar di pesantren. 
Berbeda dengan remaja di desa lainnya yang lebih bangga untuk bersekolah di kota. Dengan banyaknya remaja yang bersekolah di pesantren juga mempengaruhi gaya hidup dan fashion mereka. Mereka tidak terlalu mengunggulkan penampilannya.

Terkait isu tersebut menurut penulis ini sangat menarik untuk diteliti, maka penulis mengangkat sebuah judul Pola Pendidikan Keluarga dalam Membendung Gaya Hidup Hedonis di Lingkungan Perindustrian (Studi di Desa Mentoso Kecamatan Jenu Kabupaten Tuban Jawa Timur).

\section{B. Rumusan Masalah}

Berdasarkan latar belakang di atas, maka yang menjadi rumusan masalah pada pokok pembahasan ini adalah:

1. Bagaimana gaya hidup hedonis di lingkungan perindustrian desa mentoso kecamatan Jenu kabupaten Tuban?

2. Bagaimana pola pendidikan keluarga di lingkungan perindustrian desa mentoso kecamatan Jenu kabupaten Tuban?

\section{Tujuan Penelitian}

Sebagaimana rumusan masalah yang dikemukakan di atas, maka tujuan penelitian ini adalah:

1. Untuk mengetahui gaya hidup hedonis di lingkungan perindustrian desa mentoso kecamatan Jenu kabuaten Tuban.

2. Untuk mengetahui pola pendidikan keluarga di lingkungan perindustrian desa mentoso kecamatan Jenu kabuaten Tuban.

\section{Penelitian Terdahulu}

Berdasarkan penelusuran yang telah dilakukan terkait dengan penelitian tentang Pola Pendidikan keluarga dalam membendung gaya hidup hedonis di lingkungan perindustrian, terdapat beberapa hasil penelitian terdahulu yang tertuang dalam beberapa karya ilmiah diantaranya:

Pertama, penelitian skripsi yang dilakukan oleh Taufiqurrahman mahasiswa institute Agama Islam Negeri Antasari yang berjudul Pola pendidikan keluarga dalam membina dan mengarahkan perilaku sosial anak: studi kasus pada orang tua siswa SDN di Kecamatan Banjar Timur. Penelitian ini menyimpulkan bahwa pola pendidikan keluarga yang otoriter dibenci oleh Islam karena akan melahirkan generasi yang lemah 
dan gagap dalam menyongsong masa depan, serta akan menyebabkan anak tidak berkembang. Sehingga sebagian besar kemungkinan terjerumus kepada jalan yang tidak sesuai dengan syariat Islam dan mengalami tekanan yang akut. Pola pendidikan yang demokratis yang penuh dengan kasih sayang, peneladanan, pembiasaan dan diskusi adalah yang memadai dalam mendidik anak.

Kedua, Skripsi Jurusan Psikologi, Fakultas Pendidikan Psikologi UM, 2012 oleh Koriys Destueg Etyng yang berjudul Hubungan Pola Asuh Dan Status Sosial Ekonomi Dengan Gaya Hidup Hedonis Pada Remaja SMA Negeri 3 Malang. Tujuan penelitian ini adalah untuk mengetahui hubungan antara pola asuh dan status sosial ekonomi dengan gaya hidup hedonis remaja di SMA Negeri 3 Malang. Rancangan penelitian ini adalah deskriptif korelasional. Berdasarkan hasil analisis korelasi ada hubungan antara pola asuh dengan gaya hidup hedonis pada remaja SMA Negeri 3 Malang.

Ketiga, penelitian yang dilakukan oleh Dauzan Deriyansyah Praja dan Anita Damayantie dalam jurnal Sociologie Vol 1, No 3 (2013) yang berjudul Potret Gaya Hidup Hedonis Di Kalangan Mahasiswa (Studi pada Mahasiswa Sosiologi FISIP Universitas Lampung). Penelitian ini bertujuan untuk mengetahui dan menjelaskan bagaimana faktor menyebabkan hedonis, bentuk lain dari hedonis, gaya hidup dan berdampak pada gaya hidup hedonis di kalangan siswa. Berdasarkan penelitian yang dilakukan diperoleh hasil yang menyebabkan faktor gaya hidup hedonis pada informan adalah teman pergaulan yang juga memiliki gaya hidup yang sama, media faktor seperti internet sering menawarkan kesenangan instan, dan ada juga faktor lingkungan tentang tindakan tidak sensitif menyimpang dari mahasiswa, serta kurangnya kontrol orang tua dari gaya hidup anaknya.

Sedangkan dalam penelitian yang berjudul pola pendidikan keluarga dalam membendung gaya hidup hedonis di lingkungan perindustrian desa mentoso kec. Jenu kab. Tuban ini akan membahas mengenai gaya hidup hedonis, pola pendidikan keluarga, tingkat keberhasilannya dan mengetahui faktor pendukung dan penghambat pola pendidikan keluarga di lingkungan perindustrian desa mentoso kec. Jenu kab. Tuban.

\section{E. Landasan Teori}

\section{Pola Pendidikan Keluarga}

\section{a. Pendidikan Keluarga}

Secara etimologi kata "keluarga" menurut K.H.Dewantara adalah rangkaian perkataan-perkataan 'kawul' dan 'masyarakat'. Sebagaimana diketahui, 
maka 'kawul' itu tidak lain artinya dari pada 'abdi' yakni "hamba" sedangkan "masyarakat" berarti "anggota". Sebagai "abdi" di dalam "keluarga" wajiblah seseorang di situ menyerahkan kepentingan-kepentingannya kepada keluarganya. Sebaliknya sebagai "masyarakat" atau "anggota" ia berhak sepenuhnya pula untuk ikut mengurus segala kepentingan di dalam keluarganya tadi. Jika ditinjau dari ilmu sosiologi, keluarga adalah bentuk masyarakat kecil yang terdiri dari beberapa individu yang terikat oleh suatu keturunan, yakni kesatuan antara ayah, ibu dan anak yang merupakan kesatuan kecil dari bentuk-bentuk kesatuan masyarakat (Abu Ahmadi, 1991: 162).

Adapun pengertian keluarga dalam Islam adalah kesatuan masyarakat terkecil yang dibatasi oleh nasab (keturunan) yang hidup dalam suatu wilayah yang membentuk suatu struktur masyarakat sesuai syari'at Islam, atau dengan pengertian lain yaitu suatu tatanan dan struktur keluarga yang hidup dalam sebuah sistem berdasarkan agama Islam (Abdul Aziz, 2005: 73).

Lingkungan keluarga merupakan lingkungan pendidikan yang pertama, karena dalam keluarga inilah anak pertama-tama mendapatkan didikan dan bimbingan. Juga dikatakan lingkungan yang utama, karena sebagian besar dari kehidupan anak adalah di dalam keluarga, sehingga pendidikan yang paling banyak diterima oleh anak adalah dalam keluaga. Keluarga juga merupakan satu tempat awal bagi anak dalam mengenal nilai-nilai sosial. Di dalam keluarga, akan terjadi contoh kecil pendidikan sosial bagi anak. Misalnya memberikan pertolongan bagi anggota keluarga yang lain, menjaga kebersihan dan keindahan dalam lingkungan sekitar.

Peletakan dasar-dasar keagamaan masa kanak-kanak adalah masa paling baik dalam usaha menanamkan nilai dasar keagamaan. Kehidupan keluarga yang penuh dengan suasana keagamaan akan memberikan pengaruh besar kepada anak. Kebiasaan orang tua mengucapkan salam ketika akan masuk rumah merupakan contoh langkah bijaksana dalam upaya penanaman dasar religius anak (Hasbullah, 2012:57). Oleh karena itu, kehidupan keluarga yang harmonis perlu dibangun di atas dasar sistem interaksi yang kondusif sehingga pendidikan dapat berlangsung dengan baik.

Dari definisi keluarga di atas, maka dapat disimpulkan bahwa pendidikan keluarga adalah pendidikan yang berlangsung dalam keluarga yang dilaksanakan 
oleh orang tua sebagai tugas dan tanggung jawabnya dalam mendidik anak dalam keluarga. Sedangkan fungsi orangtua dalam pendidikan keluarga adalah: (1) pendidikan budi pekerti, (2) pendidikan sosial, (3) pendidikan kemasyarakatnegaraan, (4) pembentukan kebiasaan, dan (5) pendidikan intelek

\section{b. Pola Pendidikan Keluarga}

Kamus besar bahasa Indonesia pola mengartikan pola sebagai model, contoh, pedoman, dasar kerja. Sedangkan pola dalam kamus ilmiah populer diartikan sebagai mode, contoh, pedoman (rancangan); dasar kerja, bentuk. Menurut Neong Muhadjir yang dikutip oleh Mustajab bahwa segala sesuatu itu berkembang, di dalamnya ada proses tumbuh, adaptasi, seleksi, dan persaingan (pola fikir evalusioner) (Mustajab, 2012:35).

Sedangkan pendidikan yang dimaksudkan dalam penelitian ini adalah pendidikan nonformal atau pendidikan yang dikelola oleh masyarakat, hal ini sebagaimana termuat dalam UU SISDIKNAS No. 20 Tahun 2003 pasal 54 tentang peran serta masyarakat dalam pendidikan. Adapun bunyinya sebagai berikut:

1. Peran serta masyarakat dalam pendidikan meliputi peran serta perorangan, kelompok, keluarga, organisasi profesi, pengusaha dan organisasi kemasyarakatan dalam penyelenggaraan dan pengendalian mutu pelayananpendidikan.

2. Masyarakat dapat berperan serta sebagai sumber, pelaksana dan pengguna hasil pendidikan.

3. Ketentuan mengenai peran serta masyarakat sebagaimana dimaksud dalam ayat (1) dan (2) diatur lebih lanjut dengan pera turan pemerintah.

Dengan demikian bisa disimpulkan bahwa pola pendidikan keluarga adalah mode, contoh, pedoman (rancangan); dasar kerja, atau bentuk yang diterapkan oleh keluarga dalam memberikan pendidikan kepada anggota keluarganya, sebagai bagian dari peran serta masyarakat dalam pendidikan.

\section{c. Pola Pendidikan Keluarga dalam Islam}

Salah satu tugas utama orang tua adalah mendidik keturunannya. Dengan kata lain relasi antara anak dan orang tua itu secara kodrati tercakup unsur pendidikan untuk membangun kepribadian anak dan mendewasakannya. Ditambah dengan adanya menjadi agen pertama dan terutama yang mampu dan berhak menolong keturunannya serta wajib mendidik anak-anaknya (Kartini Kartono, 
1997:59). Dalam sebuah keluarga yang Islami tentu pendidikan sangatlah penting. Untuk itu perlu adanya pola pendidikan atau pola asuh yang diterapkan pada keluarga dalam Islam. Pola ini yang biasa kita kenal dengan parenting Islami.

Parenting Islami penting adanya dalam sebuah keluarga. Sebab, untuk menciptakan peradaban yang baik dimulai dari keluarga. Sama halnya ketika Rasulullah mendapat perintah dari Allah untuk menyampaikan Alquran. Hal yang diajarkan pertama kali oleh beliau adalah keluarganya, lalu para sahabatnya, hingga keseluruh umat manusia.

Abdullah Nashih Ulwan menyebutkan, dalam Islam, metode dan sarana pendidikan yang berpengaruh pada anak adalah sebagai berikut: 1) Mendidik dengan keteladanan, 2) Mendidik dengan kebiasaan, 3) Mendidik dengan nasihat, 4) Mendidik dengan perhatian/pengawasan, 5) Mendidik dengan hukuman. Sedangkan materi pendidikan anak dalam keluarga menurut Islam adalah: 1) pendidikan Aqidah, 2) pendidikan ibadah, 3) pendidikan akhlak, 4) pendidikan jasmani, 5) pendidikan akal (Abdullah Nashih, 2013: 516).

Beberapa bentuk ekspresi orang tua dalam mengasuh dan anaknya bisa dalam bentuk sikap atau tindakan verbal maupun non verbal. Ekspresi ini dapat diartikan sebagai pola asuh. Secara subtansial, sangat berpengaruh terhadap potensi diri anak dalam aspek intelektual, emosional maupun kepribadian, perkembangan sosial dan aspek psikis lainnya.

Terdapat tiga pola asuh, yaitu pola asuh otoriter, gaya membolehkan (pola asuh permisif) dan gaya memerintahkan (pola asuh autoritatif). Pola asuh otoriter adalah tipe pola asuh dimana orang tua terlalu banyak menuntut dan sangat kurang merespon dan menanggapi keinginan anak. Pola asuh permisif, dimana orang tua sangat terlibat dalam kehidupan anak. Pola asuh autiritatif dimana pola asuh ini menerima tuntutan yang layak atau pantas dan tegas (Santrock, 1995:258).

\section{Gaya Hidup Hedonis}

\section{a. Definisi Gaya Hidup Hedonis}

Gaya hidup adalah pola tingkah laku sehari-hari segolongan manusia dalam masyarakat Minor dan Mowen menyatakan, gaya hidup menunjukkan bagaimana orang hidup, bagaimana orang membelanjakan uangnya dan bagaimana mengalokasikan waktu (J.C. Minor, 2002: 282). Sepakat dengan definisi tersebut 
Sumarwan mengatakan bahwa gaya hidup sering digambarkan dengan kegiatan, minat dan opini dari seseorang. Gaya hidup seseorang biasanya tidak permanen dan cepat berubah. Seseorang mungkin dengan cepat mengganti model dan merk pakainnya karena menyesuaikan dengan perubahan hidupnya (Ujang Sumarwan, 2004: 57).

Supranto menjelaskan bahwa gaya hidup hedonis adalah pola hidup yang mengarahkan aktivitasnya untuk mencari kesenangan hidup dan aktifitas tersebut berupa menghabiskan waktu di luar rumah, lebih banyak bermain, senang pada keramaian kota, senang membeli barang yang kurang diperlukan dan selalu ingin menjadi pusat perhatian. Gaya hidup hedonis mempengaruhi gelaja aspek perilaku konsumsi seorang konsumen. Gaya hidup seseorang merupakan fungsi karakteristik atau sifat individu yang sudah dibentuk melalui interaksi lingkungan, orang yang semula tidak boros (hemat) menjadi pemboros setelah bergaul dengan orang-orang pemboros. Gaya hidup seseorang mempengaruhi perilaku pembelian, yang bisa menentukan banyak keputusan konsumsi perorangan, jadi gaya hidup bisa berubah karena pengaruh lingkungan (Supranto, 2012: 143).

Jadi dapat disimpulkan bahwa, gaya hidup hedonis adalah pola hidup yang mengarahkan aktivitasnya untuk mencari kesenangan hidup, sehingga bentuk perilaku yang dimunculkan dalam perilaku hedonis biasanya lebih banyak menghabiskan waktu diluar rumah untuk bersenang-senang dengan temantemannya, senang membeli barang yang tidak diperlukan, dan selalu ingin menjadi perhatian di lingkungan sekitarnya.

\section{b. Gaya Hidup Hedonis Dalam Islam}

Islam dengan jelas melarang gaya hidup hedonis, hal ini sebagaimana yang disebutkan dalam Al-Qur'an surat al-Hud ayat 116:

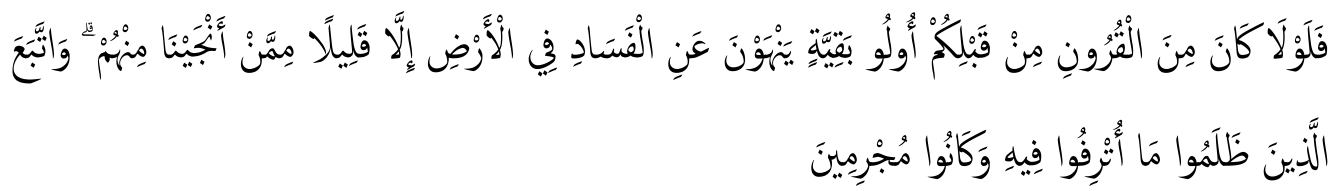

Artinya: "Maka mengapa tidak ada dari umat-umat yang sebelum kamu orang-orang yang mempunyai keutamaan yang melarang daripada (mengerjakan) kerusakan di muka bumi, kecuali sebahagian kecil di antara orang-orang yang telah Kami selamatkan di antara mereka, dan orang-orang yang zalim hanya 
mementingkan kenikmatan yang mewah yang ada pada mereka, dan mereka adalah orang-orang yang berdosa”.

Dari ayat di atas dapat kita pahami bahwa Allah telah mengingatkan kepada manusia agar tidak terjebak dalam gaya hidup hedonis karena sesungguhnya gaya hidup hedonis hanya akan merugikan diri sendiri dan kerusakan di dunia.

Dalam Surat Alfurqan ayat 67:

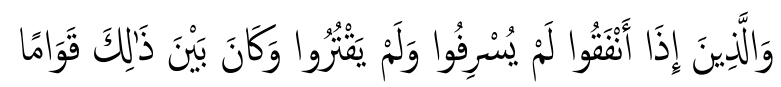

Artinya: "Dan orang-orang yang apabila membelanjakan (harta), mereka tidak berlebih-lebihan, dan tidak (pula) kikir, dan adalah (pembelanjaan itu) di tengah-tengah antara yang demikian".

Demikian pula petunjuk Al-Qur'an supaya kita sederhana dalam menggunakan harta yang diberikan Allah, sebagaimana dalam surat Al Isra Ayat 26-39:

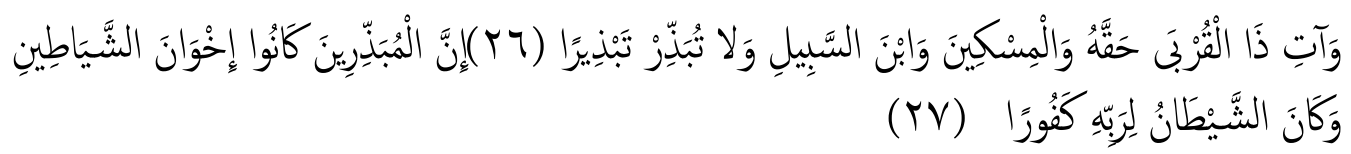

Artinya: (26) "Dan berikanlah haknya kepada kerabat dekat, juga kepada orang miskin dan orang yang dalam perjalanan; dan janganlah kamu menghamburhamburkan (hartamu) secara boros. (27) Sesungguhnya orang-orang yang pemboros itu adalah saudara setan dan setan itu sangat kufur kepada Tuhannya.

Dari ayat-ayat di atas dapat kita ambil kesimpulan bahwa Allah telah mengingatkan kepada manusia agar hidup secara sederhana, tidak mengahmburhambutkan harta (boros) dan agar membelanjakan harta sesuai kebutuhan. Artinya bahwa Islam melarang gaya hidup hedonis.

2. Pola Pendidikan Keluarga dalam Membendung Gaya Hidup Hedonis di Lingkungan Perindustrian.

Industri memiliki pengaruh yang besar untuk menimbulkan terjadinya perubahan di dalam masyarakat. Dampak industri terhadap masyarakat sangat banyak, salah satunya adalah perubahan sosial masyarakat. Perubahan social tersebut yang paling menonjol adalah perubahan gaya hidup komersil atau yang dikenal dengan 
sebutan hedonis. Saat ini, budaya hedonis sudah menjadi propaganda barat yang sukses dan mengakar dalam jiwa-jiwa remaja.

Kecenderungan gaya hidup hedonis ini harus dibendung, jika tidak maka seseorang akan terjerumus pada kecenderungan untuk bersenang-senang belaka dan berusaha untuk meraih kesenangan tersebut dengan menghalalkan segala cara serta keluar dari norma-norma moral dan khusunya nilai-nilai religius.

Kotler menyatakan bahwa faktor-faktor yang mempengaruhi gaya hidup seseorang ada dua faktor yaitu faktor yang berasal dari dalam diri individu (internal) dan faktor yang berasal dari luar (eksternal). Faktor internal antara lain : sikap, pengalaman, dan pengamatan, kepribadian, konsep diri, motif dan persepsi. Sedangkan, faktor eksternal antara lain: kelompok referensi, keluarga, kelas sosial, dan kebudayaan(1997).

Menguatkan pernyataan itu, Masbikin mengatakan bahwa keluarga adalah sebuah wadah dari permulaan pembentukan pribadi serta tumpuhan dasar fundamental dari perkembangan dan pertumbuhan anak. Lingkungan keluarga secara potensial dapat membentuk pribadi anak menjadi hidup secara tanggung jawab, apabila usaha pendidikan dalam keluarga itu gagal, akan terbentuk seorang anak yang lebih cenderung melakukan tindakan-tindakan yang bersifat kriminal. Penyebab yang paling utama di lingkungan keluarga adalah karena sifat egois dari anak tersebut, penyebab ini bisa diartikan sebagai kemauan dari anak itu sendiri atau dengan kata lain kenakalan itu terjadi karena berasal dari itu sendiri (2013).

Penjelasan di atas mengindikasikan bahwa betapa pentingnya peranan pendidikan dalam pembentukan kepribadian anak. Dasar kepribadian ini terbentuk melalui hubungan yang mendasar dalam bidang emosi yang dilandasi ikatan cinta yang kuat. Di atas dasar kepribadian inilah mengendap lapisan-lapisan baru dari watak dan kepribadian sebagai hasil sosialisasi anak dan remaja di dalam atau di luar lingkungan keluarga, dalam lingkungan kerja serta lingkungan kehidupan orang dewasa. Namun perlu ditegaskan bahwa proses sosialisasi yang manapun juga, tidak ada yang begitu dalam pengaruhnya ketimbang pengalamannya di dalam lingkungan keluarga dari masa kecilnya. Oleh karena itu, orang tua sebagai pendidik dalam keluarga perlu mempunyai formula atau pola pendidikan keluarga untuk membendung pengaruh-pengaruh negative dari lingkungan anak.

\section{F. Metode Penelitian}




\section{Jenis dan pendekatan}

\section{a. Jenis Penelitian}

Jenis penelitian ini adalah field research atau penelitian lapangan. Penelitian dapat disebut pula penelitian kualitatif. Riset kualitatif merupakan suatu pendekatan dalam melakukan riset yang berorientasi pada fenomena atau gejala yang bersifat alami. Dengan istilah lain, riset semacam ini sering disebut dengan Naturalistic Inquiry, Field Study, atau studi observasional (Mohammad Ali, 2011: 239).

\section{b. Pendekatan}

Peneliti menggunakan pendekatan ilmu pendidikan dan termasuk penelitian deskriptif kualitatif. Riset kualitatif bersifat deskriptif, dalam arti bersifat mendeskripsikan makna data atau fenomena yang dapat ditangkap oleh pelaku riset, dengan menunjukkan bukti-buktinya. Pemaknaan terhadap fenomena itu banyak bergantung pada kemampuan dan ketajamannya dalam melakukan analisis Mohammad Ali, 2011). Pendekatan tersebut akan peneliti gunakan untuk memahami dan menganalisis berkaitan dengan pola pendidikan keluarga di lingkungan perindustrian desa mentoso kec. Jenu kab. Tuban.

\section{Sumber data}

Sumber data dalam penelitian adalah subyek dari mana data itu dapat diperoleh (Auharsimi Arikunto, 2010: 107). Dalam penelitian kualitatif, informasi merupakan data yang dapat diperoleh dilokasi penelitian, dalam naskah atau dokumen, dan dari informasi yang telah ditunjuk sebagai kunci pengayaan sumber data dengan teknik purposive sampling dan snowball sampling (Sugiono, 2006: 368).

Adapun yang menjadi informan dalam penelitian ini adalah:

1) Kepala Desa Mentoso Kec. Jenu Kab.Tuban

2) Kepala Keluarga Desa Mentoso Kec. Jenu Kab.Tuban

3) Penduduk usia remaja (12-21 tahun) Desa Mentoso Kec. Jenu Kab.Tuban

4) Tokoh pendidikan dan agama Desa Mentoso Kec. Jenu Kab.Tuban

\section{Teknik pengumpulan data}

Demi melancarkan proses penelitian ini, peneliti menggunakan beberapa teknik pengumpulan data sebagai berikut:

a. Metode interview

b. Metode observasi 
c. Metode dokumentasi

\section{Keabsahan Data}

Triangulasi yang digunakan adalah triangulasi sumber berarti membandingkan dan mengecek balik derajat kepercayaan suatu informasi yang diperoleh melalui waktu yang berbeda. Hal ini dicapai dengan jalan:

a. Membandingkan data hasil wawancara dengan data hasil pengamatan.

b. Membandingkan data hasil wawancara dengan isi suatu dokumen.

c. Membandingkan hasil wawancara, pengamatan, dokumentasi kemudian mengecek hasil analisis.

\section{Teknik analisi data}

Penelitian ini merupakan penelitian kualitatif, maka data yang digali dan dihimpun dari lapangan adalah data yang disajikan dalam bentuk kata, bukan bentuk angka. Sebagaimana yang ditulis Moh. Nasir, dengan demikian analisis data yang digunakan oleh peneliti mengacu pada tiga langkah, sebagaimana diketengahkan model penyajian dan analisis data dari Miles dan Huberman yaitu:
a. Reduksi data
b. Display data
c. Penarikan Kesimpulan/Verifikasi

\section{G. Pembahasan Hasil Penelitian}

\section{a. Desa Mentoso Kecamatan Jenu}

Kecamatan Jenu terletak di Jalur Pantura. Tepatnya 10km arah barat dari Kota Tuban dengan luas wilayah $81,6 \mathrm{~km}^{2}$. Sebelah utara Kecamatan Jenu berbatasan dengan Laut Jawa, batas timur yaitu Kecamatan Tuban. Batas selatan adalah Kecamatan Merakurak. Batas barat adalah Kecamatan Tambakboyo. Kecamatan Jenu membawahi tujuh belas desa. Salah satu desanya adalah Desa Mentoso.

Desa Mentoso meliliki luas $3,5 \mathrm{~km}^{2}$. Mayoritas penduduk dewasa Desa Mentoso berpencaharian sebagai pedagang, nelayan, dan petani. Penduduk usia produktif dengan jenis kelamin laki-laki $80 \%$ bekerja di desa Mentoso itu sendiri. Sedangkan 20\% yang lain bekerja di luar kota. Penduduk usia produktif dengan jenis kelamin perempuan 80,3\% menempuh pendidikan pesantren di Jombang, Lamongan, Sarang dan di Jenu sendiri. sedangkan penduduk berjenis kelamin laki-laki mayoritas menempuh pendidikan sekolah kejuruan. 
Di Kecamatan Jenu berdiri industri-industri besar, diantaranya industri Pembangkit Listrik Tenaga Uap, PT Trans Pacific Petrochemical Indotama (TPPI) yaitu industri yang memproduksi salah satu bahan baku industri kimia, industri kemasan semen Gresik, dan lain-lain. Adanya industri yang didirikan di Kecamatan Jenu berimbas pada tingkat kesejahteraan ekonomi masyarakat secara langsung maupun tidak langsung.

Adanya industri yang secara langsung meningkatkan kesejahteraan masyarakat Desa Mentoso ketika masyarakat desa Mentoso menjadi pekerja di industri-industri tersebut. Imbas secara tidak langsung didapat saat para pekerja di industri terlibat jualbeli saat pekerja dari luar kota melengkapi kebutuhan pekerja dari luar kota membeli di toko-toko yang dimiliki masyarakat Desa Mentoso. Misalnya, masyarakat mendirikan kios makanan yang sering dikunjungi pekerja di industri ketika istirahat.

Ada pemandangan berbeda dari masyarakat Desa Mentoso dibanding desa lainnya yang sama berada dikawasan industri. Dari segi penampilan, warga Desa Mentoso terlihat sederhana. Rumah yang didirikan sederhana, kendaraan roda empat pun bukan tipe keluaran terbaru. Cara berpakaianpun sederhana. Kekayaan yang dimiliki masyarakat Desa Mentoso lebih banyak berwujud invetasi berupa tanah dan emas. Pada saat perayaan budaya karnaval desa, masyarakat Desa Mentoso juga melaksanakan dengan sederhana.

\section{b. Pola Pendidikan Keluarga di Desa Mentoso Kecamatan Jenu}

Seperti keluarga lainnya, interaksi keluarga di Desa Mentoso sangat baik. Sikap orang tua terhadap anak dalam mendidik dapat terlihat dari sikap anak terhadap orang tua. Para orang tua di Desa mentoso mendidik anank mereka tidak hanya pada pengetahuan umumnya, tetapi juga pada pemahaman keagamaann. Hal ini dapat terlihat dari banyaknya pemuda usia produktif yang menempuh pendidikan pada lembaga formal dan non formal. Masyarakat usia produktif laki-laki menempuh pendidikan di sekolah kejuaran. Masyarakat usia produktif perempuan menempuh pendidikan di sekolah yag berada pada lingkungan pesantren.

Pengetahuan dan pemahaman yang telah ditempuh mengakibatkan karakter baik, sopan, peduli dengan lingkungan, religius, dan sederhana. Tidak hanya akibat dari pendidikan, pola asuh yang dilakukan, orang tua juga berperan dalam hal ini. Para orang tua di Desa Mentoso menerapkan aturan yang jelas dengan mengharap sikap 
yang dewasa dari anak. Hal ini terlihat pada pemahaman akan konsekuensi dari perbuatan yang telah dilakukan. Para orang tua memberikan pemahaman dari contoh yang terjadi pada kesehariannya. Ketika mereka bekerja dengan tekun, maka hasil yang didapat juga akan berlimpah. Begitupun sebalikya. Ketika mereka dekat dengan Tuhan, melaksanakan apa yang diharuskan dalam agama dan menghindari apa yang dilarang dalam aturan agama, maka ketenangan yang didapat adalah ketenangan dan kenyamanan. Begitupun sebaliknya.

Para orang tua juga tidak segan mendengarkan pendapat anak, meninjau pendapat anak dan kemudian memberikan pandangan dan saran. Adanya saling keterbukaan dan komunikasi mengakibatkan adanya rasa saling menghargai. Dengan ini antara orang tua dan anak memiliki tanggung jawab sosial dan spiritual. Kesederhanaan dalam berpikir dan berpenampilan dari para orang tua dijadikan contoh oleh anak-anak mereka. Sehingga walaupun berada di lingkungan industri yang berlimpah kesejahteraannya, masyarakat desa Mentoso tetap menunjukkan kesederhanaannya.

\section{H. Daftar Pustaka}

Ahmadi, Abu dan Nur Uhbiyati, Ilmu Pendidikan, Jakarta: Rineka Cipta, 1991

Ali, Mohammad, Memahami Riset Perilaku dan Sosial, Bandung: Pustaka Cendekia Utama, 2011

Anonim, Kamus Besar Bahasa Indonesia ([t.k.], Tim Prima Pena: Gita Media Press,[ t.t.]

Arikunto, Suharsimi, Prosedur Penelitian Suatu Pendekatan Praktek, cet ke-5, Jakarta: Rineka Cipta, 2010

Arikunto, Suharsimi, Prosedur Penelitian Suatu Pendekatan Praktek, Jakarta: Rineka Cipta, 2010

Aziz, Abdul, Pendidikan Agama dalam Keluarga: Tantangan Era Globalisasi, Himmah, Bandung: Remaja Rosdakarya, 2007.

Dinas PU, Profil Kota Tuban, dari http://ciptakarya.pu.go.id/, diakses tanggal 15 Maret 2017

Djamarah, Syaiful Bahri, Pola Komunikasi Orang Tua \& Anak dalam Keluarga, Jakarta: Rineka Cipta, 2004

Felicia, Fenny, Rianda Elvinawati dan Sri Hartini, Kecenderungan Pembelian Kompulsif: Peran Perfeksionisme dan Gaya Hidup Hedonis. Psikologia: Jurnal Vol 9, No.3 tahun 2014 
Hasbullah, Dasar-dasar Ilmu Pendidikan, Jakarta : Raja Grafindo Persada,2012

Imam, Masbikin. Mengatasi Kenakalan Siswa Remaja, Riau: Zanafa Publishing, 2013

Jurnal Ilmiah Keagamaan dan Kemasyrakatan, Vol. 6, No. 15, Januari-April 2005

Kartono, Kartini, Tinjauan Holistik Mengenai Tujuan Pendidikan Nasional, Jakarta: Pradya Pramitra, 1997

Kotler, P \& Amstrong, G. Principlis of Marketing Edisi 3, alih bahasa Sindoro dan Molan. Jakarta: Prenhanlindo, 1997

Lexi J Moleong, Metodologi Peneliatian Kualitatif, Terj. Tjun Surjaman, cet ke-13, Bandung: Remaja Rosdakarya, 2006

Margareth, Kualitas Permukiman di Kecamatan pasar Kliwon (Fakultas Geografi: UGM. 2011

Minor, J.C. dan M. Mowen, Perilaku Konsumen, jilid 2, edisi ke 5 (Jakarta: Erlangga, 2002

Mustajab, Pola Pengembangan Madrasah dalam Konteks Otonomi Daerah, Tesis: UIN Sunan Kalijaga Yogyakarta, 2012

Nasir, Moh, Metode Penelitian, Bogor: Ghalia Indonesia, 2011

Pius A. Partanto dan M. Dahlan Al Barry, Kamus Ilmiah Populer (Surabaya: Arkola, [t.t.] Sugiono, Metode Penelitian Pendidikan Kuantitatif, Kualitatif, Bandung: Alfabeta, 2006

Sukardi, Metodologi Penelitian Pendidikan, Jakarta: Bumi Aksara, 2004

Sumarwan, Ujang, Perilaku Konsumen, Bogor: Ghalia Indonesia, 2004

Supranto, Pengukuran Tingkat Kepuasan Pelanggan Untuk Menaikkan Pangsa Pasar, Jakarta: Rineka Cipta, 2012

Ulwan, Abdullah Nashih, Pendidikan Anak dalam Islam, Insane Kamil, 2013

UU SISDIKNAS No. 20 Tahun 2003 pasal 54 